\title{
Электротомография аллювиальных отложений при поисковых работах на россыпное золото
}

Оленченко В. В., Осипова П. С.

\begin{abstract}
Аннотация
Метод электротомографии нашел широкое практическое применение при поисках и разведке рудных месторождений золота, однако его возможности для изучения россыпей недостаточно раскрыты. На основе численного моделирования и на примере полевых исследований показано, что выделяемые в поймах рек линейные аномалии высокого удельного электросопротивления соответствуют перспективным на золотоносность фациям плёсов и перекатов. По результатам работ на аллювиальных россыпях Камчатки, Алтая и Прибайкалья сделан вывод о высокой разрешающей способности электротомографии для решения геологических задач, что является основанием для применения этого метода как основного при поисках и разведке россыпей.
\end{abstract}

\section{Ключевые слова:}

электротомография, аллювиальная россыпь, плотик, золото, геоэлектрическая модель 


\title{
ЭЛЕКТРОТОМОГРАФИЯ АЛЛЮВИАЛЬНЫХ ОТЛОЖЕНИЙ ПРИ ПОИСКОВЫХ РАБОТАХ НА РОССЫПНОЕ ЗОЛОТО
}

\author{
В.В. Оленченко ${ }^{1,2}$, П.С. Осипова ${ }^{1,2}$ \\ ${ }^{1}$ Институт нефтегазовой геологии и геофизики им А.А. Трофимука СО РАН, \\ ${ }^{2}$ Новосибирский государственный национальный исследовательский университет
}

Введение

В структуре сырьевой базы России россыпные месторождения составляют 18 \% в запасах и $10 \%$ в прогнозных ресурсах [Митина, Вакуленко, 2016]. Аллювиальные россыпи наиболее распространенный в природе тип и самый важный источник добычи россыпного золота. Согласно [Будилин, 1992] для рационального использования бурения и оптимального размещения его объёмов, особенно на глубокозалегающих россыпях, геофизические методы исследования используются: на поисковой стадии при изучении особенностей геологического строения золотоносных площадей, покрытых рыхлыми отложениями; при локализации перспективных участков для детальных геофизических и буровых работ; при изучении рыхлых отложений и рельефа коренных пород. С целью повышения эффективности поисковых и разведочных работ с помощью геофизики предполагается решение таких задач, как определение мощности рыхлых отложений, прослеживание погребённых долин, определение мощности и иногда литологических типов рыхлых отложений, выделение таликовых зон, границ многолетнемерзлых пород. Этим нормативным документом [Будилин, 1992] регламентировано применение метода ВЭ3. В то же время отмечено, что кривые ВЭЗ часто не поддаются уверенной количественной интерпретации вследствие искажений от влияния вертикальных и наклонных границ раздела. В отличие от ВЭЗ метод электротомографии даёт возможность получать информацию на качественно новом уровне - не в виде кривых кажущегося сопротивления и разрезов изоом, а в виде двумерных и трёхмерных геоэлектрических моделей среды [Loke, Barker, 1996a, 1996б].

Метод электротомографии (ЭТ) нашел широкое практическое применение при поисках и разведке рудных месторождений [Татьков и др., 2011; Gouet et al., 2013; Куликов и др., 2014; Claude, 2014; Moreira et al., 2016; Gouet et al., 2016; Singh et al., 2019]. Это связано с хорошо разработанной методикой измерений и математическим аппаратом интерпретации данных в рамках двухмерных и трёхмерных моделей среды [Бобачев, 2013; Loke, 2009; Loke, Barker 1996 а, б]. Гораздо меньшее количество публикаций посвящено электротомографии россыпных месторождений золота.

В тезисах о проблемах современной геофизики при поисках россыпных месторождений [Белохвостик и др., 2018] сообщается, что комплекс геофизических методов определяется геологическим строением и генетическим типом россыпи. Электроразведка позволяет определить глубину плотика и расчленить разрез рыхлых отложений методом вертикального электрического зондирования, профилирования (ЭП) или электротомографии. При этом ЭТ обладает наибольшей разрешающей способностью, 
детальностью и мобильностью. Применение сейсморазведки позволяет уточнить рельеф плотика и детально расчленить разрез рыхлых отложений. При наличии в составе россыпей магнитных минералов для их поисков используется магниторазведка. Кроме того, она дает возможность выделять структурные элементы на довольно больших площадях. Для определения рельефа плотика также используют низкочастотный широкополосный георадар [Hasanov, Muravyev, 2019], который даже в условиях глинистых разрезов позволяет определять границы раздела сред. В представленных примерах даже при детальной разведке исследования проводятся на отдельных профилях, часто по нерегулярной сети, а интерпретация ограничивается анализом двумерных моделей, как, например, в [Rasskazov et al., 2017].

B работе [Давыдов, Бакаев, 2012] показаны результаты комплексирования разнообразных методов при разведке нескольких генетических типов месторождений. Исследования на россыпях ложкового, террасового и техногенного типов выполнены следующими методами: дистанционное индукционное зондирование, дипольное электромагнитное зондирование, метод радиокомпарации и пеленгации, естественного поля, переменного естественного электрического поля, магниторазведка, сейсморазведка и радиометрия. В результате сделаны выводы, что для решения геологических задач наиболее оптимально сочетание электроразведки на постоянном и переменном токе, малоглубинной сейсморазведки и магниторазведки в случае присутствия магнетита в «песках». Пример использования магниторазведки приведён в работе [Блинов и др., 2005].

Зарубежные исследования россыпных месторождений золота методом электротомографии представлены в примерах полевых работ геофизических компаний, например [Kim et al., 2009]. Оконтуривание палеорусел методами геофизики показаны в работах [Doyle, 1990; Eberle et al., 2017; Nimnate et al., 2017; Mohamed-Ali, Ibrahim, 2019; Singh et al., 2019; Ghosal et al., 2020]. Исследователи отмечают успешное применение методов наземной магниторазведки, ЭТ, ВЭЗ, аэромагнитной съёмки и аэроэлектроразведки.

Анализ публикаций показал, что метод электротомографии постепенно внедряется в практику работ при поисках и разведке россыпей золота, но мы считаем, что возможности метода остаются не до конца раскрытыми.

Основная цель наших исследований - это оценка информативности метода электротомографии при поисковых работах на россыпное золото и определение критериев геологической интерпретации геофизических данных. Работа основана на материалах, полученных авторами в течение нескольких полевых сезонов в различных регионах России на россыпях разных генетических типов.

\section{Геологическое строение аллювиальной россыпи}

Формирование большинства аллювиальных россыпей происходит на стадии зрелости реки, когда основная энергия потока расходуется на транспортировку материала [Кухаренко, 1961]. В этих условиях сильно проявлена боковая эрозия, что вызывает разрушение берегов. В результате река течет среди своих же наносов, перемывая и перемещая их. Морфологически аллювиальные россыпи делятся на три типа: террасовые, долинные (пойменные) и русловые. Однако геологические строение сохраняется одинаковым для различных типов. 
Для хорошо разработанной речной долины существуют группы аллювиальных фаций: русловые - плёсы, пристержневая зона, косы и береговые отмели и пойменные прируслового вала, приречная, внутренняя, вторичных водоемов (рис. 1, а).

Зависимость распределения тяжелой фракции аллювия от русловых процессов есть общепризнанный факт. Частицы золота, как одна из тяжелых фракций аллювия, подчиняются общим закономерностям транспорта и аккумуляции наносов, что отражается на их распределении в россыпи [Виноградова, Хмелева, 2009].

На рисунке 1, б представлен типичный для аллювиальных россыпей разрез, где отражены стадии формирования поймы по [Кухаренко, 1961]. Состав и гранулометрия слагающего долину материала существенно зависит от типа рельефа. На разрезе видно, что основная масса металла концентрируется в отложениях фации плёсов, которые представлены валунами и галечниками. Концентрирование металла связано с вихревым движением потока у дна реки, его торможением и улавливанием тяжелых минералов. В качестве связующего выступает песчаный и глинистый материал. Осадки фации перекатов («пласт»), расположенные выше, имеют различную степень сортировки аллювия. Металл здесь распределен неравномерно. Вверх по разрезу расположена фация кос и береговых отмелей («речники»), которые содержат, главным образом, тонкое золото. Отложения здесь представлены более мелким валунно-галечником. Граница между «речниками» и «пластом» условная, выделяемая лишь по данным опробования. Перекрывает русловые отложения песчано-глинистый материал пойменной фации. Значительных концентраций металла в нём не отмечается. «Пласт» залегает на плотике - коренных породах. Нередко на поверхности плотика встречаются неровности («карманы», борозды, западины), которые представляют особый поисковый интерес, так как в них происходит концентрирование полезного ископаемого [Ильенок, 1970; Шило, 2002].

Следовательно, задачей геофизических исследований на поисковой стадии является выделение в разрезе и картирование в плане отложений фации плёсов и перекатов, с которой связано золото.

Геоэлектрическая модель аллювиальной россыпи

Различие дисперсного состава отложений разных фаций отражается на их удельном электрическом сопротивлении (УЭС). Самое высокое УЭС имеют валунно-галечниковые отложения. По мере уменьшения размера фракции отложений понижается и их УЭС. При рассмотрении ряда песок-супесь-суглинок-глина УЭС пород понижается на порядок - от первых сотен до 7-10 Ом·м [Вахромеев и др., 1997; Milsom, 2003; Ward, 1990].

Что касается электрического сопротивления плотика, то оно может быть разным и зависит от его вещественного состава. Если это магматические породы незатронутые процессами выветривания, то их УЭС будет высоким - от первых тысяч до десятков тысяч Ом·м [Вахромеев и др., 1997; Ward, 1990]. Коренные породы осадочного генезиса (песчаники, алевролиты, карбонаты) на контакте с аллювием часто выветрелые, а поскольку долины рек формируются по разломам, эти породы имеют интенсивную трещиноватость с глинистым заполнителем, поэтому их УЭС значительно ниже, чем у валунно-галечниковых отложений.

Для решения прямой задачи мы использовали программy ZondRes2D версии 6.0 [Kaminsky, 2010]. На рис. 2, а показана геоэлектрическая модель, построенная на основе рис.1, а. Она включает слой песчано-глинистого материала пойменной фации мощностью 
2 м и УЭС 50 Омм, суглинки мощностью 1 м с УЭС 30 Ом·м, отложения фации кос и береговых отмелей - мелкий валунно-галечник с песчаным заполнителем мощностью 2 м и УЭС 150 Ом·м, слой валунно-галечников с песчано-глинистым заполнителем (УЭС 800 Ом·м) мощностью 2 м и плотик, представленный трещиноватым песчаником с сопротивлением 300 Ом·м. В интервале 70-84 м в плотике смоделирован «карман» локальное углубление, заполненное валунно-галечниковыми отложениями.

При решении прямой задачи выбрана прямая и обратная трехэлектродная установка (в англоязычной литературе - pole-dipole) с расстоянием между электродами, равным 2 м. На рисунке 2, б показан разрез кажущегося сопротивления $\left(\rho_{\kappa}\right)$, полученный в результате

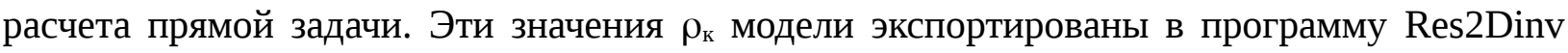
[Loke, 2002] для инверсии. Применялся робастный метод решения обратно задачи, который показывает хороший результат в контрастных по УЭС средах [Loke, 2002]. В результате получен разрез расчётного кажущегося УЭС (рис. 2, в) и разрез истинного (т.е. заданного в начальной геоэлектрической модели) УЭС (рис. 2, г). Ошибка подбора модели составила 0,66 \% на пятой итерации. Значения сопротивлений на разрезе изменяются от 45 Ом`м до 650 Ом`м. То есть сопротивление суглинков, определенное в модели в 30 Ом•м, завышается и равно примерно 45 Ом·м. Верхний слой, представленный пойменной фацией, четко выделяется на разрезе, но также имеет завышенное сопротивление 5560 Ом·м. Фация кос и береговых отмелей не имеет четких границ и выражена переходным слоем с УЭС 100-200 Ом·м. Слой валунно-галечниковых отложений определяется однозначно, хотя и с заниженным УЭС 380-650 Ом•м. Также аномалией высокого УЭС выделяется и область палеорусла или «карман» в плотике.

Согласно моделированию, высокоомный слой, соответствующий валунногалечниковым отложениям, контрастно выделяется на фоне вмещающих пород. Однако его параметры из-за принципа эквивалентности моделей [Бобачев и др., 2013] восстанавливаются с некоторой неточностью, выражающейся в заниженном УЭС и завышенной мощности. При известной глубине залегания кровли плотика, например, по одиночным шурфам и скважинам, существует возможность введения и закрепления положения этой границы в геоэлектрическую модель в процессе инверсии [Loke, 2002; Loke, 2009]. В этом случае поверхность коренных пород будет определяться точнее (рис. 3). Однако участки «карманов» будут выделяться локальными аномалиями очень высокого УЭС при неизменной мощности пласта.

Численное моделирование показало, что метод ЭТ позволяет выделить в разрезе высокоомные слои фации плесов и перекатов, что является основанием для его применения при поисках россыпных аллювиальных месторождений золота.

\section{Метод и методика полевых исследований}

Электротомография, как и метод ВЭЗ, основан на различии горных пород и руд по удельному электрическому сопротивлению. Оно рассчитывается по измеренному с помощью заземлённых питающих и приёмных линий электрическому напряжению и току. Однако принципы обработки и интерпретации данных коренным образом отличаются от ВЭ3. Главное отличие заключается в автоматической инверсии в рамках двумерной или трехмерной модели среды [Loke, Barker, 1996а, 1996б; Бобачев и др., 2006.]. Двумерная инверсия выполняется для профильных данных, в предположении, что геологическая среда аппроксимируется двумерным строением, то есть слабо меняется по простиранию. 
Трехмерная инверсия проводится по результатам площадных исследований и позволяет изучать среды со сложным геологическим строением с локальными неоднородностями, например, месторождения твердых полезных ископаемых 3 и 4 группы сложности геологического строения [Приказ..., 2006].

Технология полевых наблюдений ЭТ заключается в многократном использовании одних и те же электродов в качестве питающих и измерительных. Для измерения разности потенциалов на приемных электродах нами применяется многоканальная электроразведочная станция «Скала-48к12», коммутатор которой автоматически переключает по заданной схеме соответствующие электроды, соединенные многожильным кабелем. Последовательность подключения электродов соответствовала установкам Шлюмберже и/или дипольно-осевой.

В зависимости от требуемой глубинности и детальности изучения разреза шаг измерений по профилю (расстояние между электродами) на разных участках был равен 2, 2.5 или 5 м. Обратную задачу электроразведки решали с помощью программы Res2Dinv (автор M.H. Loke).

Геологическая интерпретация геоэлектрических разрезов и карт распределения УЭС на разных глубинах производится на основе известной зависимости УЭС от литологического состава [Вахромеев и др., 1997; Milsom, 2003; Ward, 1990].

При поисковых работах на россыпное золото зондирования проводили по отдельным профилям, расположенным, как и проектные линии шурфов или скважин, на расстояниях 200, 400 или 800 м в зависимости от ширины и протяжённости долин. Как правило, профиль начинался и заканчивался на склонах, ограничивающих долину реки.

При площадном картировании измерения ЭТ проводили на перспективных участках по серии параллельных профилей, расположенных перпендикулярно современному руслу реки на расстоянии 50 м друг от друга. Данные обрабатывали в программе трёхмерной инверсии Res3Dinv (автор M.H. Loke), по результатам которой строили объёмную геоэлектрическую модель участка и её горизонтальные срезы на разных глубинах.

\section{Террасовые россыпи}

Примеры работ

Электротомографию террасовых россыпей рассмотрим на примере работ на месторождении Кичаваям (Камчатский край).

Месторождение р. Кичаваям разведано в 80-х годах прошлого века скважинами ударно-канатного бурения в долине верхнего течения реки и в долине её левого притока руч. Разлом. По данным исследований прошлых лет месторождение представлено пойменной и террасовой россыпями. Россыпь р. Кичаваям залегала в нижних горизонтах рыхлых отложений. Золотоносный пласт в составе рыхлых отложений литологически не выделяется и оконтурен по результатам опробования разведочных выработок. По трещинам плотика золото в промышленных концентрациях проникает на глубину до 0,4 м. Рыхлые образования на площади месторождения представлены аллювиальными отложениями, сложенными гравийно-галечниковым материалом средней окатанности, песками, супесями, мелкими валунами (5-10 \%). На террасе аллювиальные отложения перекрыты продуктами солифлюкции (ил, глина, щебень). Породы плотика интенсивно 
выветрены до щебня размером 1 см (рис. 4, а). В контурах корытообразного погружения в борту канавы обнажаются валунно-галечниковые отложения с песчаным и супесчаным заполнителем, представляющие собой русловую фацию (рис. 4, б).

Для определения критериев интерпретации были выполнены опытно-методические зондирования вдоль разведочной траншеи. Измерения проведены с использованием многоэлектродной станции Скала-48. Измерения на профилях длиной 475 м были выполнены по технологии «roll-along». При этом часть измерительной линии переносили на 120 м вперед по линии профиля, что позволяло перекрывать половину предыдущей расстановки. Последовательность подключения электродов соответствовала установке Шлюмберже. Диапазон разносов АВ изменялся от 15 до 235 м. Шаг по профилю наблюдений был равен 5 м. При этом достигнута глубина исследований не менее 25 м.

На рис. 5 показан фрагмент геоэлектрического разреза вдоль горной выработки и его геологическая интерпретация, которую проводили с учетом геологических данных. Сопротивление изменяется от первых сотен до первых тысяч Ом`м. В приповерхностной части разреза до глубины 4-5 м в границах горного отвода выделяются породы с УЭС 1000-3000 Ом·м. Эти породы представлены валунно-галечниковыми отложениями русловой фации, содержащей россыпное золото. Коренные породы имеют УЭС от 250 до 2000 Ом`м, в зависимости от степени трещиноватости, и представлены сильно трещиноватыми песчаниками. Непосредственно в коре выветривания, где коренные породы разрушены до состояния щебня, УЭС понижается до 50-200 Ом•м. Как следует из рис. 5, корытообразное погружение в кровле плотика образовалось над областью пониженного УЭС в коренных породах, интерпретируемой как зона разлома. Этот же факт был отмечен в геологической характеристике района работ, где сказано, что долины ручьёв закладывались в прошлом по мелким внутриблоковым разломам.

По результатам опробования в ходе эксплуатационной разведки в процессе отработки блоков было установлено, что промышленные содержания золота отмечаются именно в выделенных по геофизическим данным корытообразных погружениях поверхности плотика, и средние содержания на пласт составили около 1 г/м ${ }^{3}$. Опытнометодические работы показали, что выделяемые приповерхностные аномалии высокого (более 1000 Ом·м) УЭС соответствуют отложениям русловой фации палеорусел, перспективным на золотоносность.

Затем в пределах лицензионной площади были выполнены площадные исследования по 32 профилям, расположенным на расстоянии 50 м друг от друга. На каждом профиле выделены и вынесены на план местности контуры палеорусел. В результате получена схема распространения отложений русловой фации (рис. 6). Контур горного отвода № 1 был отработан в предыдущие годы, а контур горного отвода № 2 разрабатывался после геофизических исследований, что дало возможность сопоставить результаты электротомографии и реального строения участка. Всего на площади исследований выделяется четыре разновозрастных палеорусла, в то время как по данным бурения 80-х годов установлены одна русловая и одна пойменная россыпи (горные отводы № 1 и № 2). Сопоставление схемы распространения русловой фации и схемы расположений буровых линий говорит о том, что при поисковых работах практически не подсечена бурением зона №1, так как она располагается на современном относительно крутом (20-25) склоне, а её протяжённость порядка 1300 м. Буровые линии пересекают зону № 1 только между профилями 18 и 24. В скважинах отмечено золото, содержание 
которого на пласт изменяется до 0,21 г/M $\mathbf{M}^{3}$, что говорит о перспективности выделенной зоны. Выделенная по геофизическим данным зона № 2 чётко укладывается в контур горного отвода № 2 с блоками подсчитанных запасов. Зона № 3 расположена выше зон № 1 и 2 по гипсометрическому уровню, она прослежена по простиранию на протяжении 780 м от профиля 18 до профиля 33. Ширина зоны 35-85 м, в среднем около 45 м. В верхней части профилей выделяется зона № 4 протяжённостью около 1200 м. Она подсечена выноской буровой линии, а в скважинах отмечено содержание золота на пласт от 0,05 до 1,43 г/м ${ }^{3}$, что говорит о целесообразности её детальных исследований.

На площади исследований между профилями 27-30 и 38-42 были выделены локальные высокоомные аномалии, связанные с многолетнемёрзлыми породами (ММП) островного типа. Наличие таких островов мерзлоты следует учитывать при планировании горных работ, так как вскрыша ММП требует существенных технических и временных затрат.

Геофизические исследования на участке Кичаваям позволили подтвердить контуры известной террасовой россыпи и выявить неустановленные ранее зоны отложения русловой фации на надпойменной террасе.

\section{Русловые и долинные россыпи}

Применение электротомографии при поисках россыпей руслового и долинного типа рассмотрим не примере исследований в Алтайском крае и в Прибайкалье.

На территории Алтайского края поисковые работы проведены на р. Ануй и её притоках в Солонешенском районе. Исследования выполнены с целью предварительной оценки геологического строения речных долин для планирования поисковых работ на россыпное золото. Основными задачами были определение мощности рыхлых отложений, выявление палеорусел.

Район исследования входит в состав медно-золоторудно-россыпного узла Ануйского района. Все разведанные россыпи в бассейне Ануя приурочены к аллювиальным отложениям речных долин, расположены в русловой части реки, пойме и 1-й надпойменной террасе. Отложения 2-й надпойменной террасы обнаруживают местами слабую золотоносность. Золотоносный пласт повсеместно представлен галечниками, залегающими на трещиноватых коренных породах. Работы выполнены на 17 профилях длиной от 235 до 955 м. Длина профилей зависела от ширины долины реки, а шаг измерений по профилю был равен 5 м. Последовательность подключения электродов соответствовала симметричной Шлюмберже и дипольно-осевой установкам. Максимальный разнос АВ при измерениях установкой Шлюмберже составил 235 м. Максимальный разнос OO' дипольно-осевой установки составил 200 м. Глубинность исследований достигала не менее 20 м. Для измерений использовали многоэлектродную электроразведочную станцию Скала-48К12.

На рисунке 7 показана часть геоэлектрического разреза по одному из профилей через долину реки Ануй. Его геологическая интерпретация выполнена с учетом данных геологической карты масштаба 1:200000. В верхней части разреза до глубины 5,5-9 м отчётливо выделяется слой высокого (700-2000 Ом`м) УЭС, интерпретируемый как рыхлые аллювиальные отложения. Они подстилаются породами пониженного сопротивления (70-200 Ом`м), которые вероятно представлены выветрелыми сланцами, алевролитами и песчаниками. В долине реки слой рыхлых отложений делится на две зоны. 
Первая зона начинается на левом берегу реки и идет до 420 м. В неё входит современное русло р. Ануй, то есть это русловой тип россыпи. Вторая зона - в интервале 430-570 м интерпретируется как палеорусло, и, следовательно, долинная россыпь. Рыхлые отложения в выделенных зонах высокого УЭС имеют валунно-галечниковый состав. С точки зрения золотоносности, эти зоны наиболее перспективные. На склоне, начиная с 670 м, отложения с низким УЭС (менее 75 Ом·м) представлены покровными суглинками.

В результате исследований на р. Ануй положительно оценена геологическая информативность метода ЭТ для решения поставленных геологических задач. По аномалиям повышенного УЭС выделены палеорусла. На участках развития карбонатного плотика выявлены карстовые «карманы», перспективные на золотоносность. В работах [Ильенок, 1970; Шило, 2002] показано, что локальные углубления плотика отличаются высокой обогащенностью.

В Прибайкалье на одной из рек Приморского хребта проведены поисковооценочные работы, включающие геофизические исследования методом ЭТ. Участок работ расположен в Иликтинско-Кургинском золотороссыпном узле. Россыпи здесь мелкозалегающие современные и погребённые, с максимальными содержаниями, приближенными к плотику. По априорной информации мощность рыхлых отложений изменяется от 2 до 5 м. Золотоносный пласт расположен в нижней части валунно-галечнопесчаных отложений и верхней части плотика. Основная часть золота (65 \%) связана с песчано-гравийно-галечными отложениями. Плотик представлен выветрелыми песчаниками, твёрдыми известняками, кварцитами, сланцами.

Измерения выполнены на 21 профиле длиной по 235 м, расположенных на расстоянии 50 м друг от друга, шаг измерений по профилю составил 5 м. Последовательность подключения электродов соответствовала дипольно-осевой и симметричной Шлюмберже установкам. Для уточнения границ аллювиальных отложений шаг измерений на одном из профилей был сгущен до 2,5 м. Пример геоэлектрического разреза с шагом 2,5 м между электродами приведен на рисунке 8. На этом разрезе приповерхностная аномалия высокого (2500-3000 Ом`м) УЭС в интервале профиля 115140 м связана с отложениями палеорусла, то есть представляют собой долинную россыпь. Аномалия более высокого УЭС (3500-6000 Ом·м) в интервале 155-180 м соответствуют отложениям русловой фации, которые связаны с современными потоками. Установленная мощность рыхлых отложений долинной фации равна 2,4 м, а русловой - около 3 м, что согласуется с априорной геологической информацией. Трещиноватые коренные породы плотика имеют УЭС 500-1000 Ом·м и контрастно отличаются по УЭС от высокоомных аллювиальных отложений. Заверка результатов ЭТ опробованием в шурфах показала, что в контурах аномалий высокого УЭС (шурф 2, 4) встречаются единичные знаки золота. Вне геофизических аномалий (шурф $1,3,5$ ) золото не обнаружено вовсе.

По результатам площадных исследований была построена карта мощности рыхлых отложений (рис. 9). По сути, она представляет собой инверсную карту глубины залегания кровли плотика и отражает закономерности осадконакопления в долине. По данным ЭТ локализуются несколько участков аллювия с повышенной до 3-4 м мощностью (т.е. углубления в плотике - карманы). Наиболее протяжённый карман размером около 30х120 м выделяется между профилями 14-17. В его пределах обнаружены старые добычные шурфы размером $4 \times 4$ м, из которых вероятно добывалось золото около 100 лет назад. 
В результате исследований на Приморском хребте установлены границы отложений русловой фации перспективной на золотоносность, оконтурены подсчётные блоки для оценки прогнозных ресурсов категории $\mathrm{P}_{2}$. Такая оценка возможна по геофизическим аномалиям, природа и перспективность которых установлены единичными выработками [Приказ ..., 2006].

\section{Заключение}

Существующая нормативная база, регулирующая методики поисков и разведки россыпей золота, не содержит рекомендаций по применению конкретных современных геофизических методов для решения геологических задач [Методические рекомендации, 2007]. За последние 30 лет геофизические технологии существенно развились, изменилась аппаратура и программное обеспечение для обработки данных, что дало возможность получать качественно новый результат интерпретации. В отличие от метода ВЭЗ электротомография позволяет исследовать геологические среды сложного строения, однако до настоящего времени возможности метода при поисках россыпей остаются недостаточно изученными.

В результате проведённых исследований с помощью численного эксперимента на геоэлектрической модели аллювиальной россыпи положительно оценена разрешающая способность метода электротомографии для выделения высокоомных отложений русловой фации и определения особенностей строения рельефа плотика.

По данным полевых работ на Камчатке, Алтае и в Прибайкалье установлено, что критериями геологической интерпретации для выделения русловой фации аллювия служат локальные аномалии повышенного и высокого УЭС от 500 Ом·м до нескольких тысяч Ом•м. В плане они представляют собой лентообразные аномалии, которые маркируют палеорусла. Подобные аномалии выявляются в результате площадных зондирований в долинах рек.

Показано, что электросопротивление аллювиальных отложений современных русловых россыпей существенно выше, чем УЭС русловой фации долинных и террасовых россыпей, что даёт возможность различать эти виды россыпей на геоэлектрических разрезах.

Электротомография показала высокую разрешающую способность для определения мощности рыхлых отложений, прослеживания палеорусел, определения литологических типов рыхлых отложений, выделения границ многолетнемерзлых пород, что представляется основанием для рекомендации этого метода как основного при поисках и разведке россыпей.

Исследования проведены при поддержке проекта ФНИ 0331-2019-0007.

Литература

Министерство природных ресурсов Российской Федерации. Приказ от 11 декабря 2006 г. № 278. Об утверждении классификации запасов и прогнозных ресурсов твердых полезных ископаемых. ФБУ "Государственная комиссия по запасам полезных ископаемых"

Методические рекомендации по применению Классификации запасов месторождений и прогнозных ресурсов твердых полезных ископаемых. Россыпные 
месторождения/ - Москва: Федеральное государственное учреждение «Государственная комиссия по запасам полезных ископаемых», 2007, - 64 с.

Белохвостик Д. М. и др. Проблемы современной геофизики при поисках россыпных месторождений золота и металлов платиновой группы // Редакционная коллегия: Садовничий РВ, Медведев АС, Рыбникова ЗП. - 2018. - С. 209.

Блинов А. А. и др. О возможности применения магнитометрии при поисках россыпей золота в аллювии //Вестник Северо-Восточного федерального университета им. МК Аммосова. - 2005. - Т. 2. - №. 4.

Бобачев А. А. и др. Электротомография методом сопротивлений и вызванной поляризации //Приборы и системы разведочной геофизики. - 2006. - Т. 2. - С. 14-17.

Бобачев А.А., Большаков Д.К., Модин И.Н., Шевнин В.А. Электроразведка. Кн. Том II. Москва: МГУ. - 2013. - 124 с.

Будилин Ю. С. и др. Методика разведки россыпей золота и платиноидов //М.: ЦНИГРИ. - 1992.

Вахромеев Г. С., Ерофеев Л. Я., Канайкин В. С. Петрофизика. - Томск: Изд-во ТГУ, 1997. - 462 c.

Виноградова О.В., Хмелева Н.В. Русловые процессы и формирование аллювиальных россыпей золота. М.: МГУ, 2009. - 171 с.

Давыдов В. А., Бакаев В. П. Геофизика на россыпных месторождениях золота //Разведка и охрана недр. - 2012. - №. 4. - С. 41-47.

Ильенок С. С. Влияние неотектоники на формирование россыпей участка Восточного склона Кузнецкого Алатау //Известия Томского политехнического университета. Инжиниринг георесурсов. - 1970. - Т. 239. с.380.

Куликов В. А., Бобачев А. А., Яковлев А. Г. Применение электротомографии при решении рудных задач до глубин 300-400 м // Геофизика. - 2014. - №. 2. - С. 39-46.

Кухаренко А. А. Минералогия россыпей. - Госгеолтехиздат, 1961. - Т. 11961.

Митина Э. А., Вакуленко Е. А. Современное состояние, проблемы и перспективы развития золотодобывающей отрасли России // Инновационная наука. - 2016. - №. 8-1.

Татьков Г. И. и др. Результаты применения современных методов электроразведки в золоторудных районах Республики Бурятии // Минерагения Северо-Восточной Азии. 2011. - С. 161-162.

Шило Н. А. Учение о россыпях: Теория россыпеобразующих рудных формаций и россыпей. Изд. 2-е, перераб. и доп. Владивосток: Дальнаука. - 2002. - 576 с.

Claude N. P. et al. Evidence of iron mineralization channels in the Messondo area (Centre-Cameroon) using geoelectrical (DC \& IP) methods: a case study //International Journal of Geosciences. - 2014. - T. 2014.

Ghosal S. et al. Delineation of Heavy Mineral Bearing Placers by Electrical Resistivity and Radiometric Techniques Along Coastal Odisha, India.

Gouet D. H. et al. Gold Mineralization Channels Identification in the Tindikala-Boutou Area (Eastern-Cameroon) Using Geoelectrical (DC \& IP) Methods: A Case Study. - 2013.

Gouet D. H. et al. Combined Geoelectrical Approach DC and IP Methods in the Identification of the Mineralized Bodies Parallel to the NE-SW Tectonic Line of Kadei River: Case of Quartz or Pegmatite Gold Bearing Veins of Ngoura Subdivision (East Cameroon) //International Journal of Geosciences. - 2016. - T. 7. - №. 7. - C. 891-903. 
Doyle H. A. Geophysical exploration for gold; a review //Geophysics. - 1990. - T. 55. №. 2. - C. 134-146.

Eberle D. et al. Locating hidden channels for placer gold exploration in the Cariboo District, British Columbia, Canada: A case study //Journal of Applied Geophysics. - 2017. - T. 136. - C. 61-79.

Hasanov I. M., Muravyev L. A. Perspectives of Gpr Application in the Geophysical Complex for Prospecting and Exploration of Alluvial Gold Deposits //Engineering and Mining Geophysics 2019 15th Conference and Exhibition. - European Association of Geoscientists \& Engineers, 2019. - T. 2019. - №. 1. - C. 1-10.

Kaminsky A. E. ZondRes2D // Software for two-dimensional interpretation of DC resistivity and IP data. Zond Geophysical Software, Saint-Petersburg (Russia). - 2010.

S. Kim, M. J. Yoon, S. G. Kim and D. J. Kwon, "Exploration Report Colomine Placer Gold Project Cameroon,” Geotech Consultant Co., Ltd., Seoul, 2009, p. $87 . \quad$ [Citation Time(s):2]

Loke M. H. RES2DINV ver. 3.50 //Rapid 2-D resistivity and IP inversion using the least square method. - 2002.

Loke M.H. Tutorial: 2-D and 3-D electrical imaging surveys. - 2009. - 144 p.

M. H. Loke, and R.D. Barker, Practical techniques for 3D resistivity surveys and data inversion: Geophysical prospecting, 44, 499-523, 1996.

M. H. Loke, and R. D. Barker, Rapid least-squares inversion of apparent resistivity pseudo-sections using quasi-Newton method: Geophysical Prospecting, 48, 181-152, 1996

Milsom J. Field geophysics. - John Wiley \& Sons, 2003. - T. 31

Mohamed-Ali M. A., Ibrahim S. A. Geophysical and Geochemical Exploration of the Gold Bearing Placer Deposits in the Southern Blue Nile (Sudan) //On Significant Applications of Geophysical Methods. - Springer, Cham, 2019. - C. 147-150.

Moreira C. A. et al. Geophysical modeling in gold deposit through DC Resistivity and Induced Polarization methods //REM-International Engineering Journal. - 2016. - T. 69. - №. 3. - C. 293-299.

Nimnate P. et al. Imaging and locating paleo-channels using geophysical data from meandering system of the Mun River, Khorat Plateau, Northeastern Thailand //Open Geosciences. - 2017. - T. 9. - №. 1. - C. 675-688.

Rasskazov I. Y. et al. Geophysical survey of deep alluvial gold in terms of Bolotisty deposit // Eurasian mining. - 2017. - № 2.

Singh R. K. et al. Imaging Regional Geology and Au-Sulphide mineralization over Dhanjori greenstone belt: Implications from 3-D Inversion of Audio Magnetotelluric data and Petrophysical Characterization //Ore Geology Reviews. - 2019. - T. 106. - p. 369-386.

Ward S. H. Geotechnical and Environmental Geophysics, chapter Resistivity and Induced Polarization Methods // Investigations in Geophysics No. 5. Soc. Expl. Geophys. - 1990. - p. 147-189. 
Рис. 1. Фации аллювиальных отложений (а) и типовой разрез долинной россыпи (б) по [Кухаренко, 1961]: 1 - коренные породы; 2 - пойменная фация; 3 - фация кос и береговых отмелей; 4 - фация перекатов (пристержневая); 5 - склоновые отложения; 6 фация плёсов (перлювиальная); 7 - прирусловой вал; 8 - уровни реки; М - межень; П паводок.

Рис. 2. Физико-геологическая (геоэлектрическая) модель долины реки (а), разрез наблюденных кажущихся УЭС (б), разрез расчётного кажущегося УЭС (в), результат 2-D инверсии модельных данных (в): 1 - вода; 2 - песчано-глинистый материал пойменной фации; 3 - суглинки; 4 - фация кос и береговых отмелей (мелкий валунно-галечник с песчаным заполнителем); 5 - валунно-галечник с песчано-глинистым заполнителем; 6 песчаник трещиноватый.

Рис. 3. Результат инверсии модельных данных с закреплённой границей: 1 граница кровли коренных пород.

Рис. 4. Выветрелые породы плотика (а) и валуны русловой фации (б) в разрезе траншеи на участке Кичаваям.

Рис. 5. Геоэлектрический разрез вдоль разведочной траншеи (а) и его интерпретация (б) с учётом геологических данных: 1 - границы горного отвода; 2 - кровля коренных пород по данным геофизики и вскрыши; 3 - рыхлые отложения русловой фации; 4 - кора выветривания коренных пород, щебень; 5 - песчаники; 6 - трещиноватые песчаники зоны разлома; 7 - разломы: а) - магистральный сместитель, б) - краевой сместитель.

Рис. 6. Схема распределения аллювиальных отложений русловой фации по геофизическим данным: 1 - границы зоны отложений русловой фации № $1 ; 2$ - границы зоны отложений русловой фации № 2; 3 - границы зоны отложений русловой фации № 3; 4 - границы зоны отложений русловой фации № 5; 5 - границы многолетнемерзлых пород; 6 - контур горного отвода; 7 - геофизический профиль (номер профиля-номер электрода); 8 - изогипсы рельефа.

Рис. 7. Геоэлектрический разрез через долину реки Ануй, Алтай: I - русловая россыпь; II - долинная россыпь; 1 - аллювий; 2 - глинистые сланцы; 3 - интенсивно выветрелые и трещиноватые коренные породы; 4 - подошва аллювиальных отложений (кровля плотика); 5 - границы перспективного участка отработки россыпи.

Рис. 8. Геоэлектрический разрез долины по данным ЭТ в Приморском хребте, Прибайкалье: I - долинная россыпь; II - русловая россыпь; III - плотик; 1 - границы перспективного участка отработки россыпи; 2 - подошва аллювиальных отложений (кровля плотика); 3- заверочные шурфы.

Рис. 9. Карта мощности рыхлых отложений по данным электротомографии, Прибайкалье: 1 - геофизические профили; 2 - река; 3 - изогипсы. 
a)

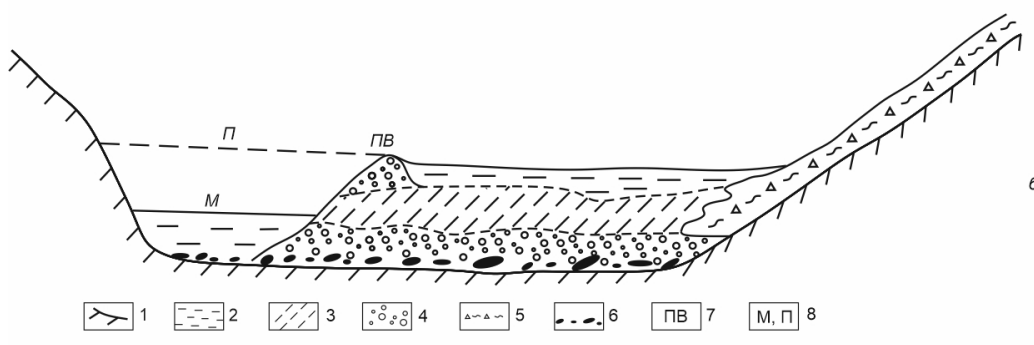

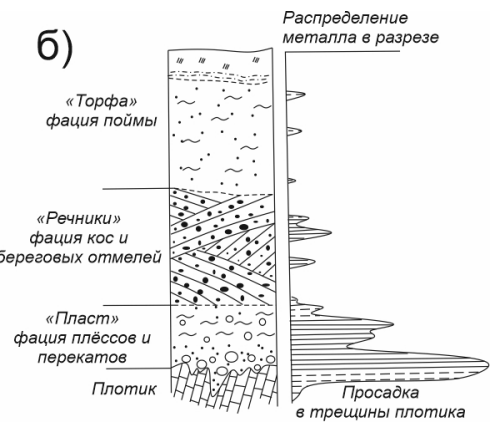


a)
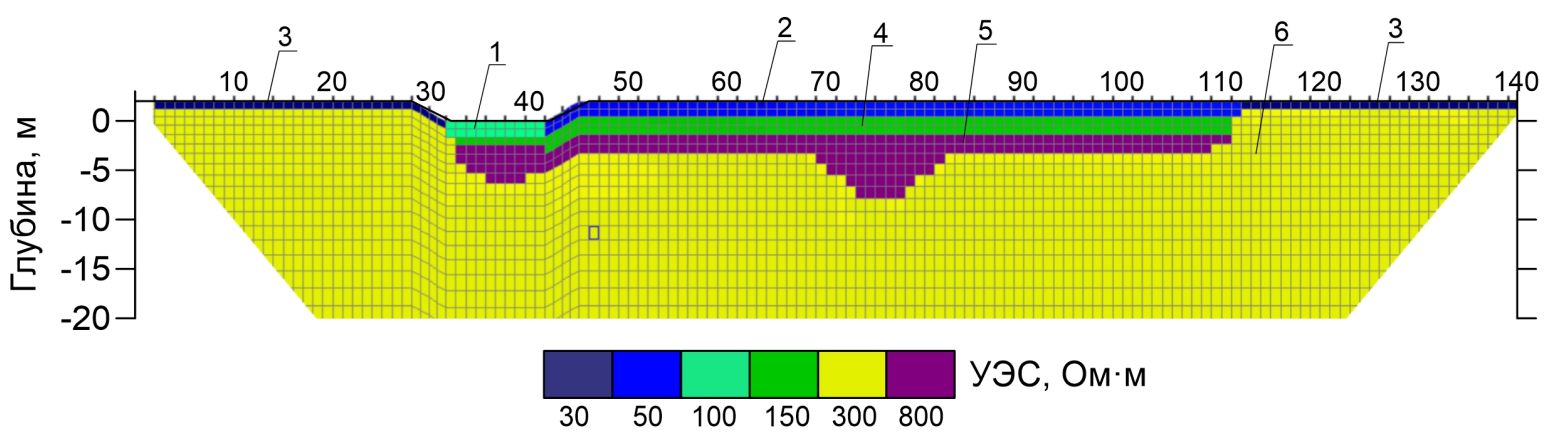

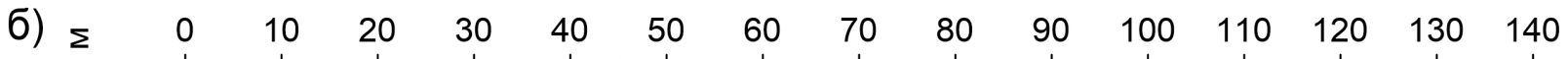

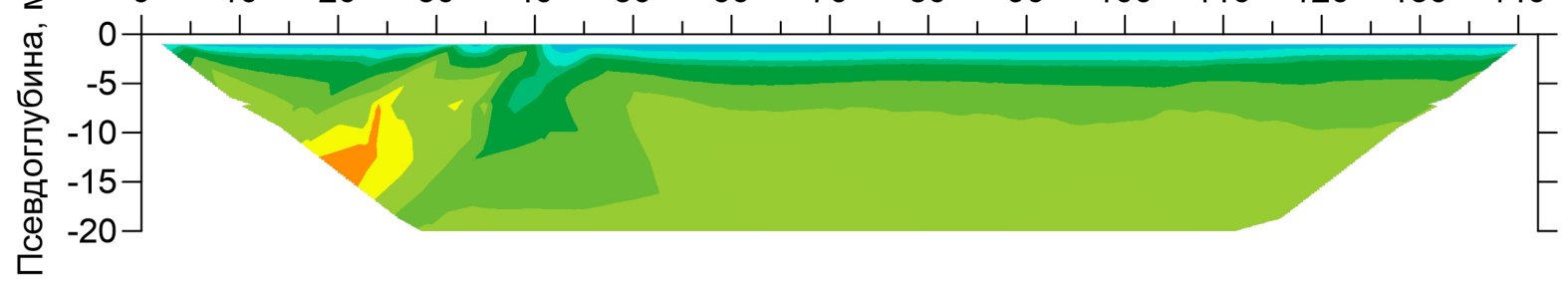

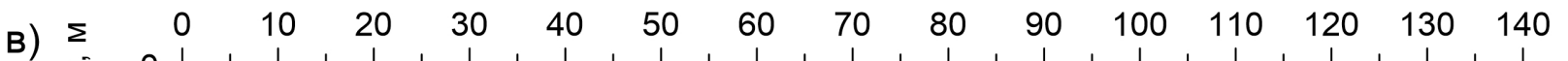

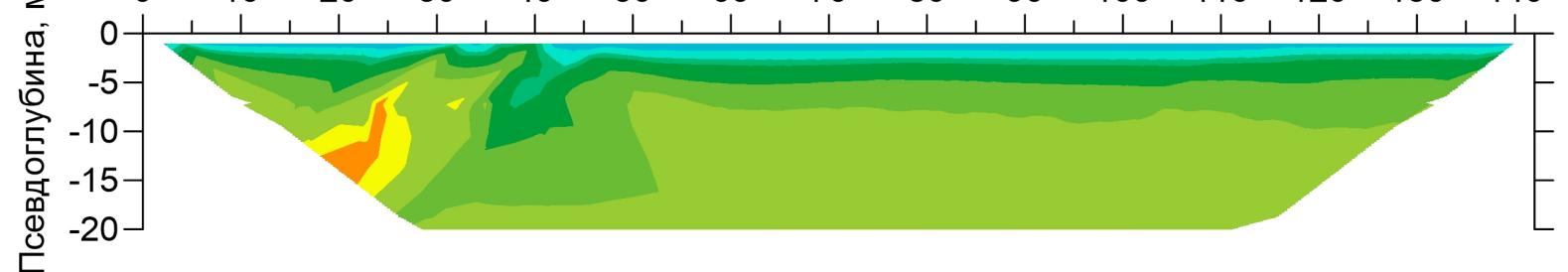

г)
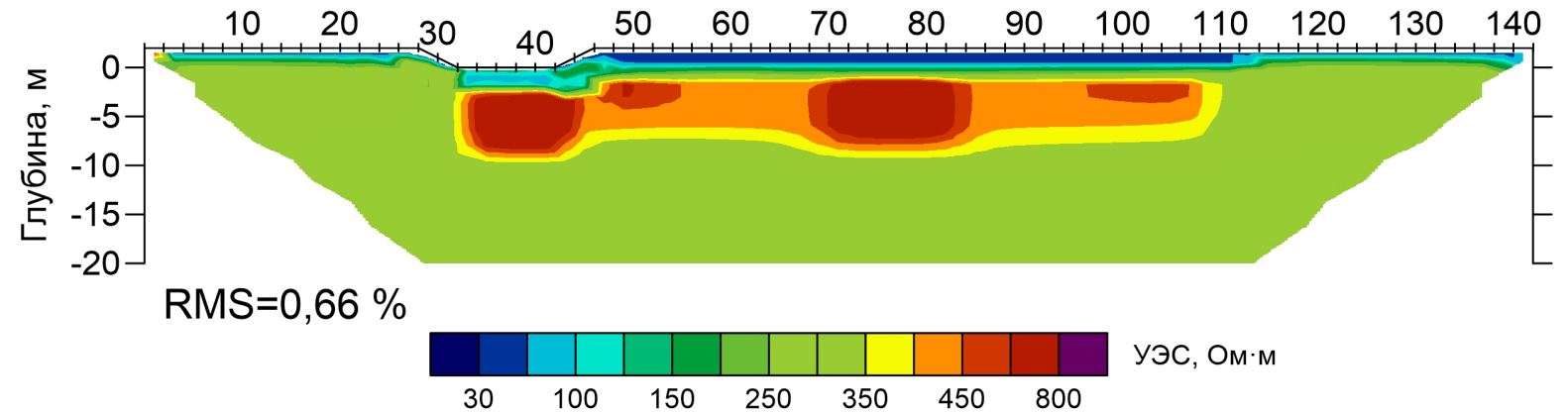


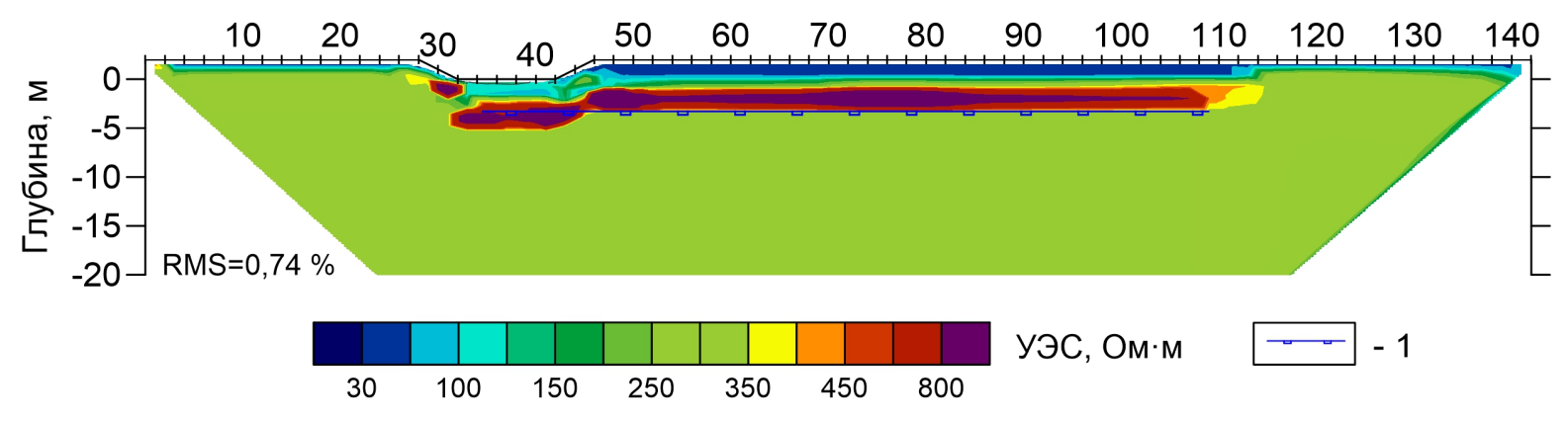


a)

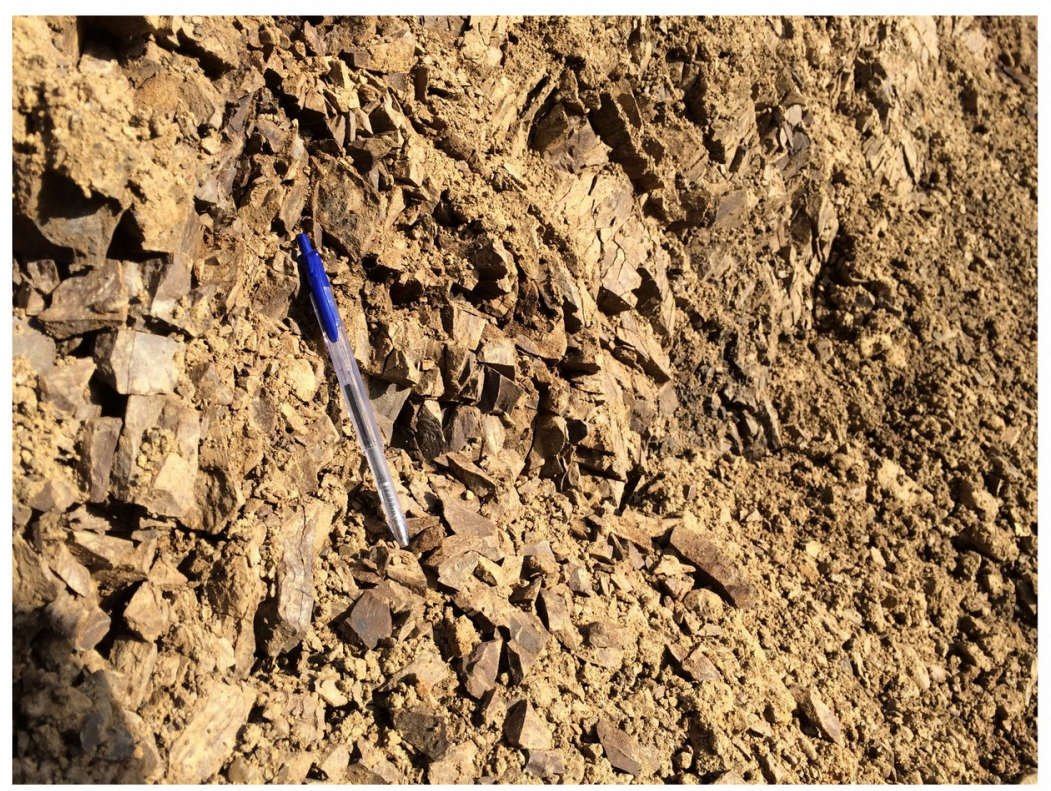

б)

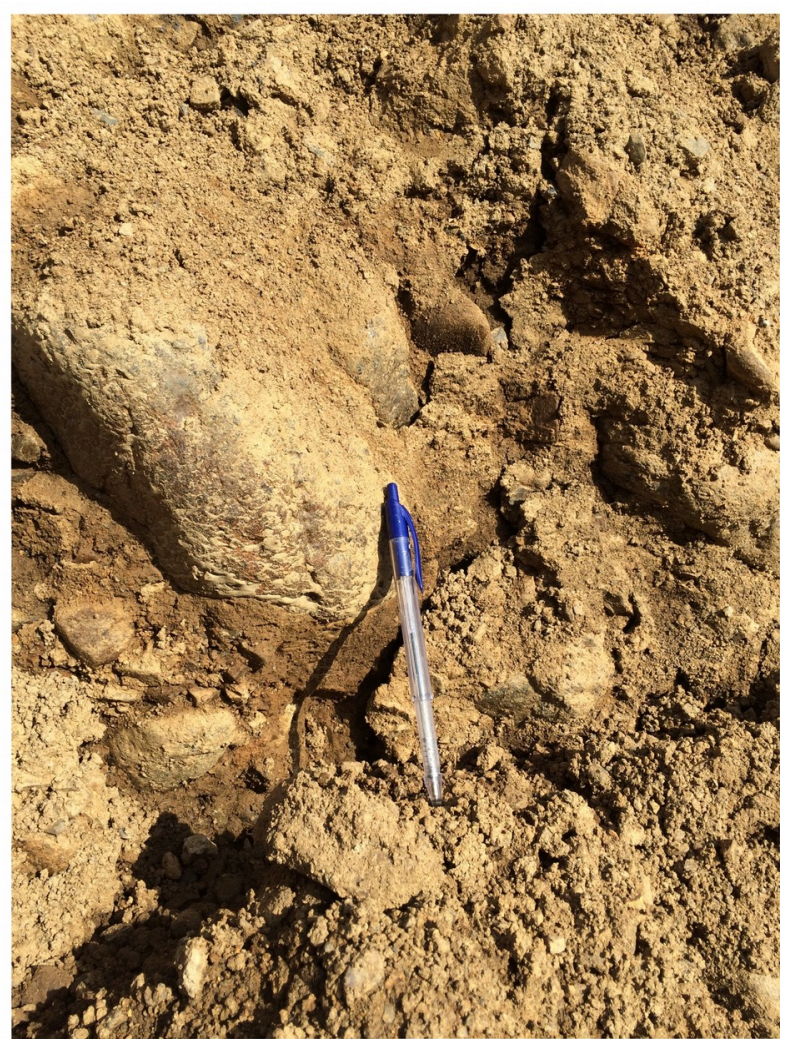




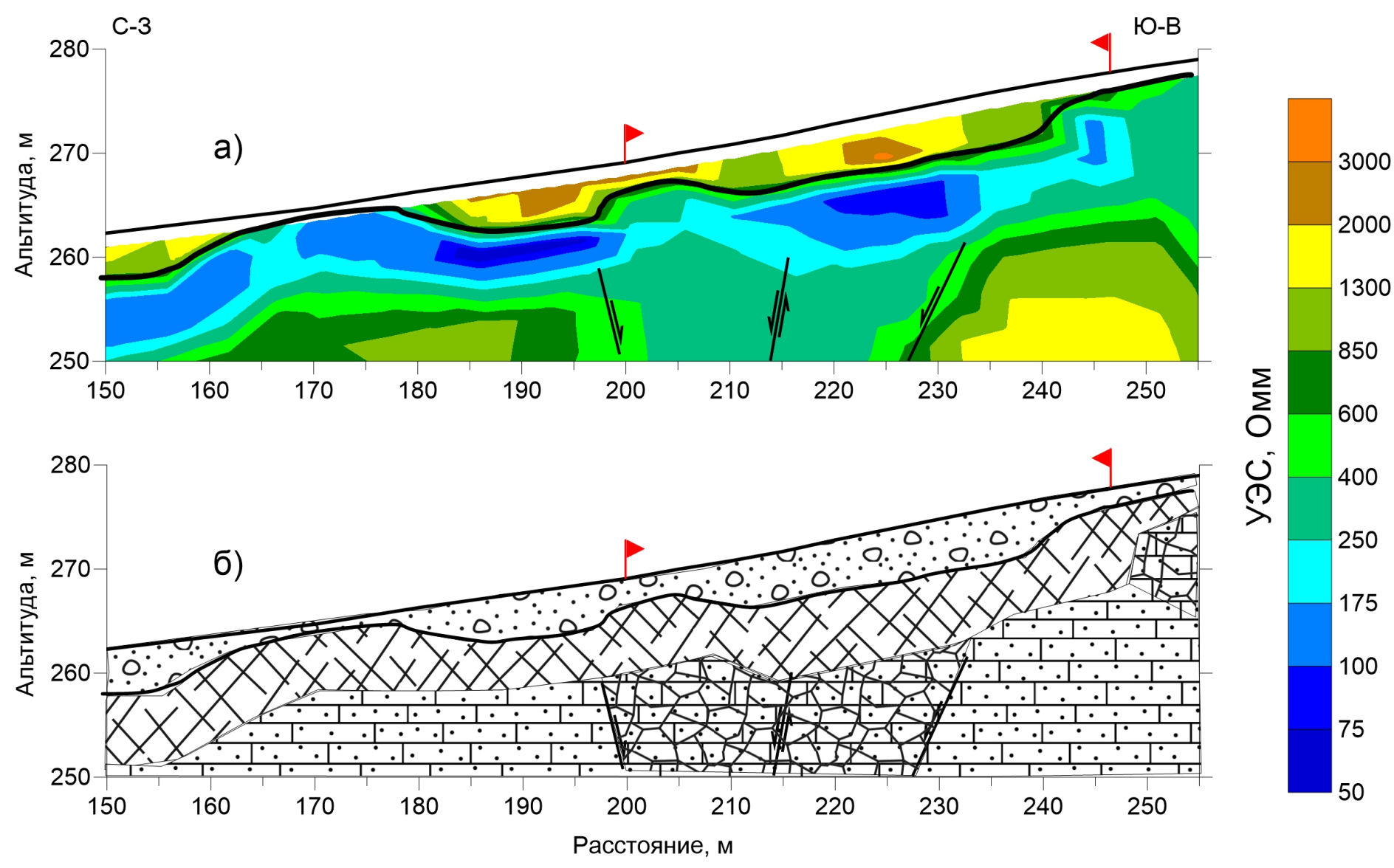

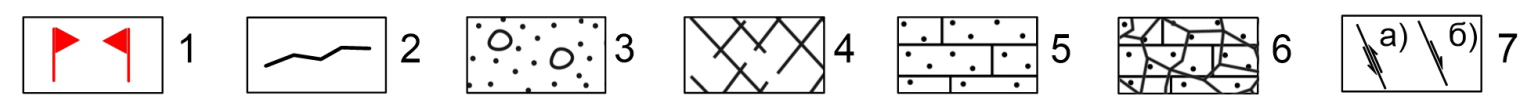



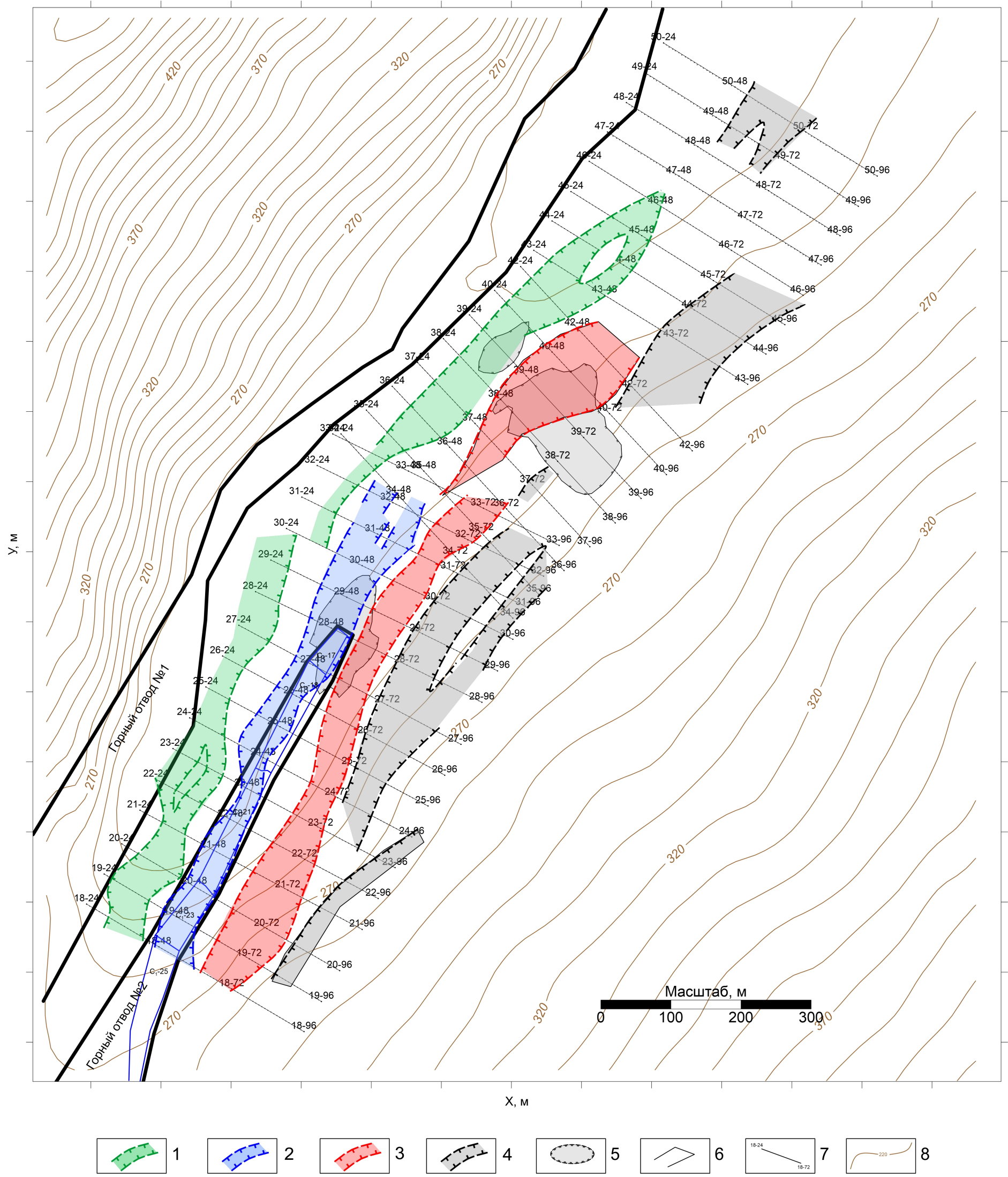


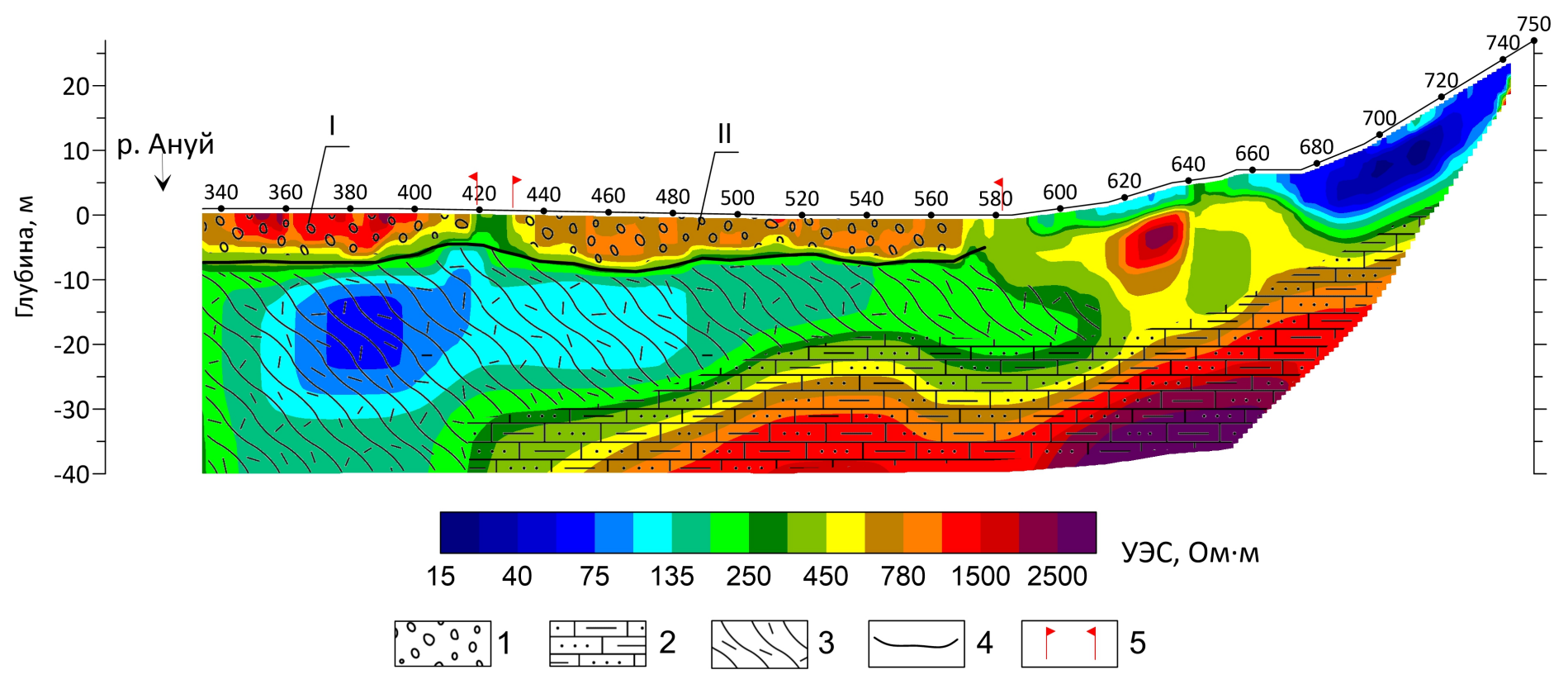




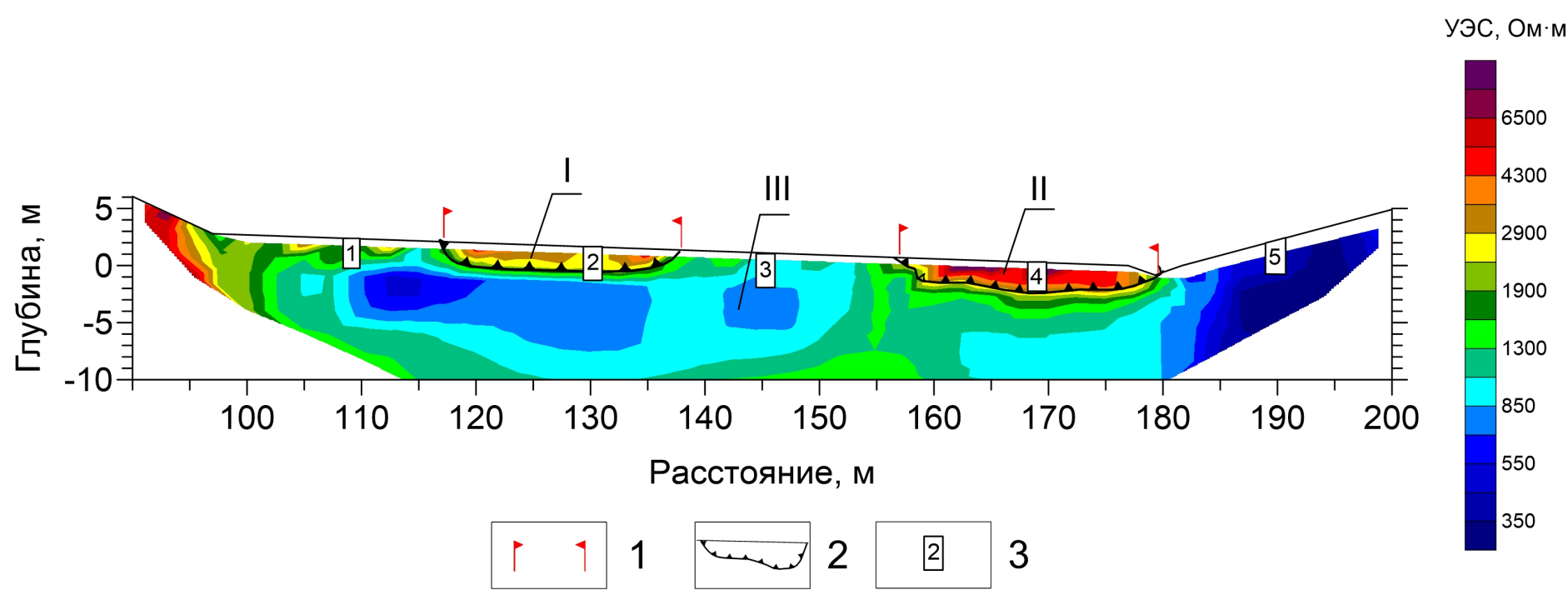




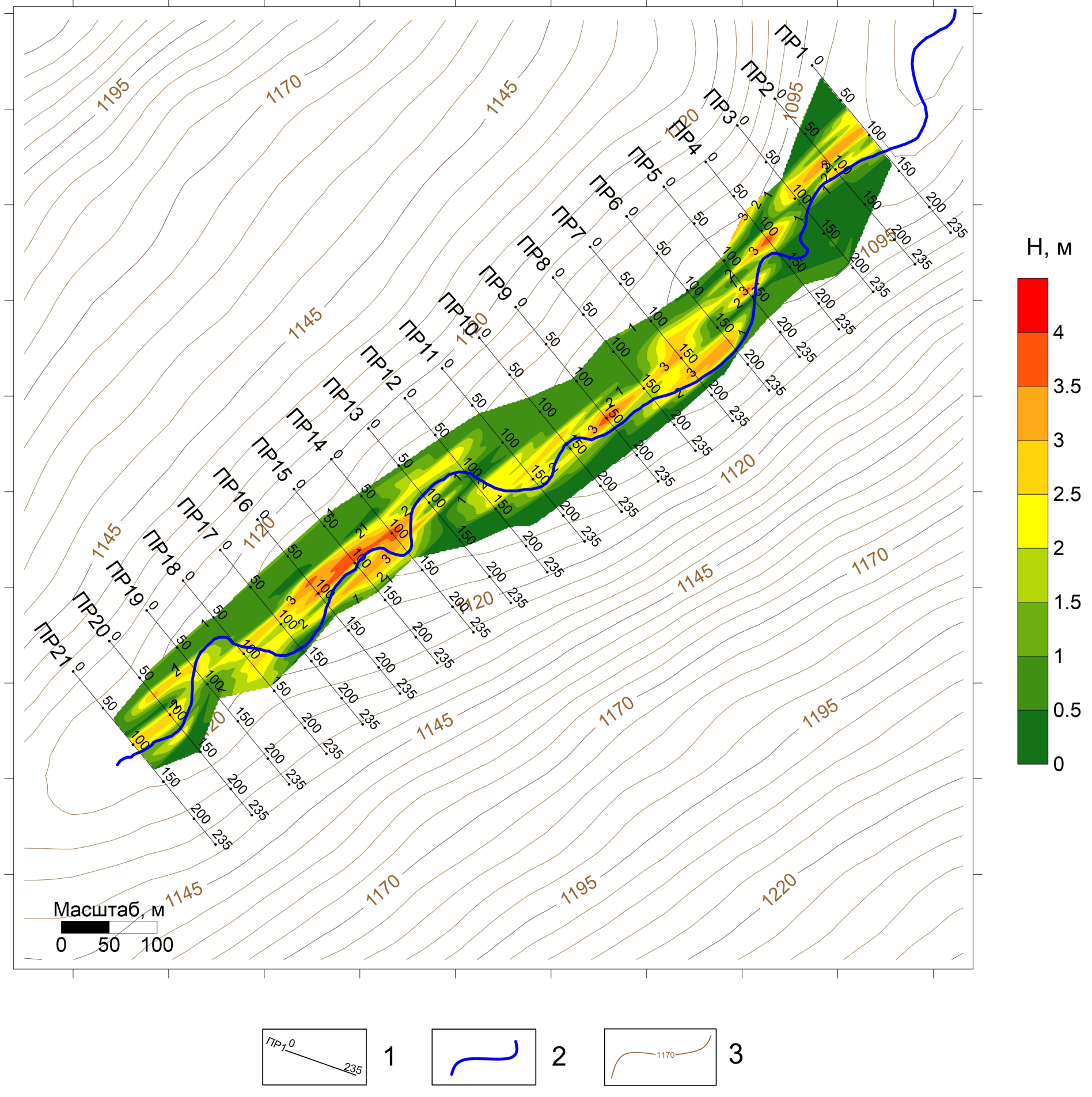

